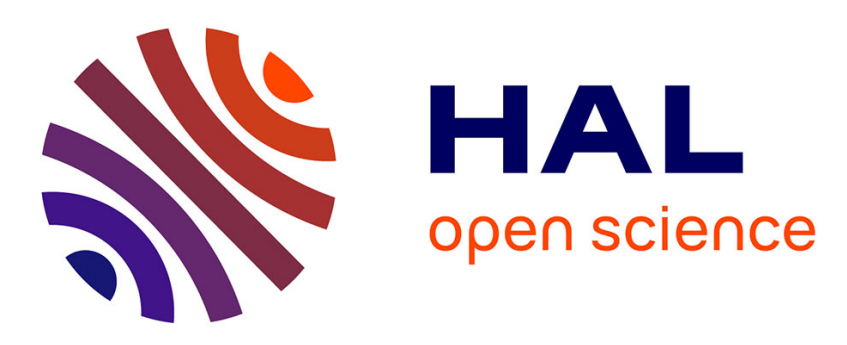

\title{
Volcanic edifice weakening via decarbonation: a self-limiting process?
}

Silvio Mollo, Michael Heap, Gianluca Iezzi, Kai-Uwe Hess, P. Scarlato, Donald B. Dingwell

\section{- To cite this version:}

Silvio Mollo, Michael Heap, Gianluca Iezzi, Kai-Uwe Hess, P. Scarlato, et al.. Volcanic edifice weakening via decarbonation: a self-limiting process?. Geophysical Research Letters, 2012, 39, pp.L15307. 10.1029/2012GL052613 . hal-00724856

\section{HAL Id: hal-00724856 https://hal.science/hal-00724856}

Submitted on 12 Oct 2021

HAL is a multi-disciplinary open access archive for the deposit and dissemination of scientific research documents, whether they are published or not. The documents may come from teaching and research institutions in France or abroad, or from public or private research centers.
L'archive ouverte pluridisciplinaire $\mathbf{H A L}$, est destinée au dépôt et à la diffusion de documents scientifiques de niveau recherche, publiés ou non, émanant des établissements d'enseignement et de recherche français ou étrangers, des laboratoires publics ou privés.

$$
\text { Copyright }
$$




\title{
Volcanic edifice weakening via decarbonation: A self-limiting process?
}

\author{
Silvio Mollo, ${ }^{1}$ Michael J. Heap, ${ }^{2}$ Gianluca Iezzi, ${ }^{3}$ Kai-Uwe Hess, ${ }^{4}$ Piergiorgio Scarlato, ${ }^{1}$ \\ and Donald B. Dingwell ${ }^{4}$
}

Received 5 June 2012; revised 30 June 2012; accepted 5 July 2012; published 10 August 2012.

[1] The inherent instability of volcanic edifices, and their resultant propensity for catastrophic collapse, is a constant source of volcanic risk. Structural instability of volcanic edifices may be amplified by the presence of carbonate rocks in the sub-volcanic strata, due to the debilitating response of carbonates to thermally-induced alteration. Nonetheless, decarbonation reactions (the primary weakening mechanism), may stall when the system becomes buffered by rising levels of a reaction product, carbon dioxide. Such thermodynamic stalling might be inferred to serve to circumvent the weakness of volcanic structures. However, the present study shows that, even when decarbonation is halted, rock physical properties continue to degrade due to thermal microcracking. Furthermore, as a result, the pathways for the escape of carbon dioxide are numerous within a volcanic edifice. Therefore, in the case of an edifice with a subvolcanic sedimentary basement, the generation of carbon dioxide via decarbonation is unlikely to hinder its impact on instability, and thus potentially devastating flank collapse. Citation: Mollo, S., M. J. Heap, G. Iezzi, K.-U. Hess, P. Scarlato, and D. B. Dingwell (2012), Volcanic edifice weakening via decarbonation: A self-limiting process?, Geophys. Res. Lett., 39, L15307, doi:10.1029/2012GL052613.

\section{Introduction}

[2] Sub-volcanic carbonate basements are common (e.g., Mt. Etna, Mt. Vesuvius, the Colli Albani volcanic district, the Campi Flegrei volcanic district (all Italy), Popocatépetl volcano (Mexico), Yellowstone volcanic system (USA), and Merapi (Indonesia)). Volcanic edifices are inherently unstable [Acocella and Puglisi, 2010]. Their propensity for failure and collapse provides a constant threat to those who live within the shadow of an active volcano. The integrity of the sub-volcanic foundation is likely to play a key role in edifice instability [Van Wyk de Vries and Borgia, 1996]. Recent studies have highlighted that volcanoes with a carbonate sub-volcanic basement may be especially prone to instability, due to their susceptibility to debilitating thermallyinduced alteration [Mollo et al., 2011a; M. J. Heap et al.,

\footnotetext{
${ }^{1}$ Istituto di Geofisica e Vulcanologia, Rome, Italy.

${ }^{2}$ Laboratoire de Déformation des Roches, Institut de Physique de Globe de Strasbourg, UMR 7516 CNRS, EOST, Université de Strasbourg, Strasbourg, France.

${ }^{3}$ Dipartimento DIGAT, Università G. d'Annunzio, Chieti, Italy.

${ }^{4}$ Earth and Environment, Ludwig Maximilians Universität, Munich, Germany.

Corresponding author: S. Mollo, Istituto di Geofisica e Vulcanologia, Via di Vigna Murata 605, I-00143 Roma, Italy. (mollo@ingv.it)

C2012. American Geophysical Union. All Rights Reserved. 0094-8276/12/2012GL052613
}

Calcination-driven weakening of the carbonate basement under Mt. Etna volcano (Italy): Implications for volcano instability, submitted to Journal of Volcanology and Geothermal Research, 2012]. The experiments of Mollo et al. [2011a] and Heap et al. (submitted manuscript, 2012) were however performed in an "open" system where the gaseous products generated by thermal decomposition could readily escape. While this provides useful primary insight, the most debilitating chemical reaction - the decarbonation of calcium carbonate $\left(\mathrm{CaCO}_{3} \rightarrow \mathrm{CaO}+\mathrm{CO}_{2}\right)-$ might be arrested when the $\mathrm{CO}_{2}$ concentration in the system is high [Khinast et al., 1996; Wang and Thomson, 1995; Samtani et al., 2002]. In such a "closed" system, where decarbonation is hindered, rock physical properties might be expected to suffer less and edifice stability could therefore be less compromised than previously anticipated. To this end, and to compliment the data of Mollo et al. [2011a] and Heap et al. (submitted manuscript, 2012), we have performed a suite of high-temperature decarbonation experiments on carbonate rock under controlled $\mathrm{CO}_{2}$ conditions (i.e., to reproduce the conditions of an "open" and a "closed" system). The resultant samples were then assessed in terms of their chemical and physical properties. We discuss these data in terms of volcano stability.

\section{Materials and Methods}

[3] For the purpose of this investigation, we use Mt. Etna volcano (Southeast Sicily, Italy) as a case study. Mt. Etna represents an ideal candidate for our study. (1) It is the largest (45 km wide stratovolcano standing $3.3 \mathrm{~km}$ above sea level), most active, and best-monitored volcano in Europe. (2) The thin basaltic cover rests on a vast (10 km thick) subvolcanic carbonate basement, i.e., the Hyblean Plateau [Lentini, 1982]. (3) The Hyblean Plateau is exposed to high temperatures as a result of proximal magma storage volumes [e.g., Tibaldi and Groppelli, 2002; Bonforte et al., 2009; Bonaccorso et al., 2010]. Additionally, Etnean magmas are considered to be stored at extremely high temperatures, ranging from 1200 to $1150^{\circ} \mathrm{C}$ [Del Gaudio et al., 2010; Mollo et al., 2010a, 2011b]. The material used in this study was Mt. Climiti limestone (MCL), from the thick-bedded bio-calcarenite units in the Monti Climiti Formation of the Sortino Group, i.e., within the carbonates of the Hyblean Plateau [Grasso and Lentini, 1982]. Cylindrical core samples $(25 \mathrm{~mm}$ in diameter and $50-60 \mathrm{~mm}$ in length) were prepared from the same set of blocks as in Heap et al. (submitted manuscript, 2012).The MCL of this study had an initial connected porosity of 0.32 and was essentially $100 \mathrm{wt} \%$ calcite. 
[4] Decarbonation experiments were conducted in a vertical tube gas-mixing furnace at the HP-HT Laboratory of Experimental Volcanology and Geophysics at the Istituto Nazionale di Geofisica e Vulcanologia (INGV, Rome). According to Le Chatelier's principle, the presence of $\mathrm{CO}_{2}$ should be the main rate-limiting factor of the decarbonation of calcite, irrespective of the amount of carbonate material and the grain particle size [Khinast et al., 1996; Wang and Thomson, 1995; Samtani et al., 2002]. From a thermodynamic point of view, it is the carbon dioxide fugacity $\left(f \mathrm{CO}_{2}\right)$ rather than the $\mathrm{CO}_{2}$ partial pressure that governs the chemical equilibrium of decarbonation [Wenzel et al., 2002; Barnes et al., 2005; Mollo et al., 2010b; Di Rocco et al., 2012]. Magma chambers emplaced in carbonate substrate: Petrogenesis of skarn and cumulate rocks and implication on $\mathrm{CO}_{2}$-degassing in volcanic areas, submitted to Journal of Petrology, 2012]. In our decarbonation experiments we therefore chose to vary the $f \mathrm{CO}_{2}$ of the system. This means that the progression of the decomposition of a carbonate rock $\left(\eta_{\mathrm{dec}}\right)$ should be inversely proportional to the $f \mathrm{CO}_{2}$ of the system. The $\eta_{\mathrm{dec}}$ value represents the ratio of the $\mathrm{CO}_{2}$ released during $\mathrm{CaCO}_{3}$ partial decomposition to the total $\mathrm{CO}_{2}$ content at the end of the reaction, and will range from 0 to 1 (i.e., $\eta_{\text {dec }}=1$ means that all the $\mathrm{CaCO}_{3}$ has fully decomposed). Our experimental samples were first inserted into a Pt-coil and then suspended within the hot zone of the furnace. The $f \mathrm{CO}_{2}$ was imposed using a gas mixture of $\mathrm{CO}_{2}+\mathrm{CO}+$ air. In this study we reproduced the conditions expected for (1) an "open" system where the $\mathrm{CO}_{2}$ can be rapidly and efficiently removed $\left(\log f \mathrm{CO}_{2}=-4.41\right)$ and, (2) a "closed" system where the $\mathrm{CO}_{2}$ cannot escape $\left(\log f \mathrm{CO}_{2}=-3\right.$ to -1.01$)$. Although the system can be considered "closed", we ran experiments at $\log f \mathrm{CO}_{2}=$ $-1.01,-2.00$, and -3.00 in order to assess any potential impact on rock physical and chemical properties. A target temperature of $750^{\circ} \mathrm{C}$ was reached using a constant heating rate of $10^{\circ} \mathrm{C} / \mathrm{min}$, to minimise thermal shock in the samples [Mollo et al., 2011a]. For each $f \mathrm{CO}_{2}$ we ran two experiments, one where the sample was kept at the target temperature for 2 hours, and another for 12 hours. The samples were then cooled at the same rate $\left(10^{\circ} \mathrm{C} / \mathrm{min}\right)$. This target temperature was guided by the thermogravimetric (TG) analyses of Heap et al. (submitted manuscript, 2012) who showed that, for MCL, $\mathrm{CaCO}_{3}$ starts to decompose at temperatures above $680^{\circ} \mathrm{C}$, and has a strong endothermic peak at $860^{\circ} \mathrm{C}$. The wt.\% of $\mathrm{CO}_{2}$ released from the rock during the decarbonation process was calculated at the end of each experiment.

[5] In order to understand the impact of the temperature at which decarbonation has been observed to ensue under variable $f \mathrm{CO}_{2}$ (i.e., "open" and "closed") conditions on rock physical properties, we determined the porosity, ultrasonic velocities, $\mathrm{Vp} / \mathrm{Vs}$ ratio, dynamic elastic moduli, and the uniaxial compressive strength (UCS) of our test samples. Porosity measurements were performed using the tripleweight water saturation method. Ultrasonic velocities were measured using an Agilent Technologies DSO5012A digital storage oscilloscope, an Agilent Technologies 33210A, $10 \mathrm{MHz}$ function/waveform generator and two broadband PZT piezoelectric transducer crystals $(100 \mathrm{kHz}$ to $1 \mathrm{MHz}$ frequency) located at the top and bottom of the sample. All measurements were collected under a force of $600 \mathrm{~N}$ to ensure a good contact between the endcaps and the sample.
Ultrasonic velocities were subsequently used to calculate the dynamic Young's modulus $\left(\mathrm{E}_{\mathrm{d}}\right)$ and the dynamic Poisson's ratio $\left(\nu_{\mathrm{d}}\right)$ [Guéguen and Palciauskas, 1994]. Finally, UCS experiments were performed on the samples using the uniaxial press at the Laboratoire de Déformation des Roches (LDR, Université de Strasbourg). Samples were loaded at a constant strain rate of $1.0 \times 10^{-5} \mathrm{~s}^{-1}$ until failure. Axial strain and force were continuously monitored during experimentation by means of an LVDT transducer and a load cell, respectively.

[6] The impact of decarbonation under different $f \mathrm{CO}_{2}$ conditions (i.e., "open" and "closed") conditions on the chemical properties of our test samples was achieved by thermogravimetric (TG) and differential scanning calorimetric (DSC) analyses [carried out at the Sektion Mineralogie, Petrologie and Geochemie (SMPG) of Ludwig Maximilians Universität (LMU) in Munich (Germany) using a Netzsch STA 449 C thermobalance apparatus] and X-ray powder diffraction pattern(XRPD) analyses [performed at the DIGAT department of Università G. d'Annunzio in Chieti (Italy) by means of a Siemens D-5005 diffractometer; the collected data were then used for determining the quantitative mineral phase amounts by the Rietveld method.]. Finally, microstructural analyses were carried out using the JEOL-JSM6500F Field Emission Gun - Scanning Electron Microscope (FE-SEM) located at the HP-HT Laboratory in Rome (INGV).

\section{Results and Discussion}

[7] MCL rock physical properties (porosity, ultrasonic wave velocities, $\mathrm{Vp} / \mathrm{Vs}$, UCS, and dynamic elastic moduli) are plotted as a function of $\eta_{\mathrm{dec}}$ (carbonate decomposition progression, see above) in Figure 1 for the experiments held at 2 hours (grey circles), those held at 12 hours (white circles), and for the "as-collected" material (black squares). The $\mathrm{CO}_{2}$ emission calculated for each sample is also presented in Figure 1a. Our data illustrates that rock physical properties showed a progressive deterioration, and that the wt.\% of $\mathrm{CO}_{2}$ emission increased, as $\eta_{\mathrm{dec}}$ increased.

[8] In the "open" system, the thermal dissociation of $\mathrm{CaCO}_{3}$ progressed and the value of $\eta_{\mathrm{dec}}$ reached 0.38 after 2 hours (releasing 9.85 wt. $\%$ of $\mathrm{CO}_{2}$ ) and 1.0 after 12 hours (releasing 42.48 wt. $\%$ of $\left.\mathrm{CO}_{2}\right)$. After 2 hours $\left(\eta_{\mathrm{dec}}=0.38\right.$ ), MCL rock physical properties had deteriorated and, after 12 hours $\left(\eta_{\mathrm{dec}}=1\right)$, they were drastically altered from the "as-collected" material $\left(\eta_{\mathrm{dec}}=0\right)$ (Figure 1). After 12 hours, the Vp, Vs, UCS, and dynamic Young's modulus decreased by $61,66,64$, and $89 \%$, respectively; whereas the porosity, $\mathrm{Vp} / \mathrm{Vs}$ ratio, and Poisson's ratio increased by 28,13 , and $24 \%$, respectively. The axial stress-strain curve for the experiment held for 12 hours is shown in Figure 2. The curve shows that, although there was substantial post-peak strain-softening, the deformation behaviour was still brittle. Sample failure was sluggish and there was no clear stress drop, although the mode of failure was axial splitting (see inset on Figure 2). Our chemical and mineralogical analyses (a combination of TG, DSC, and XRPD analyses) indicated that, under "open" conditions, a new hydrous phase (i.e., portlandite) and $\mathrm{CaO}$ (i.e., lime) formed at the expense of calcite (Figure 3). The amount of calcite progressively decreased, and hence the amount of portlandite and lime increased, as $\eta_{\text {dec }}$ increased (Figure 3 ), reflecting the progress 


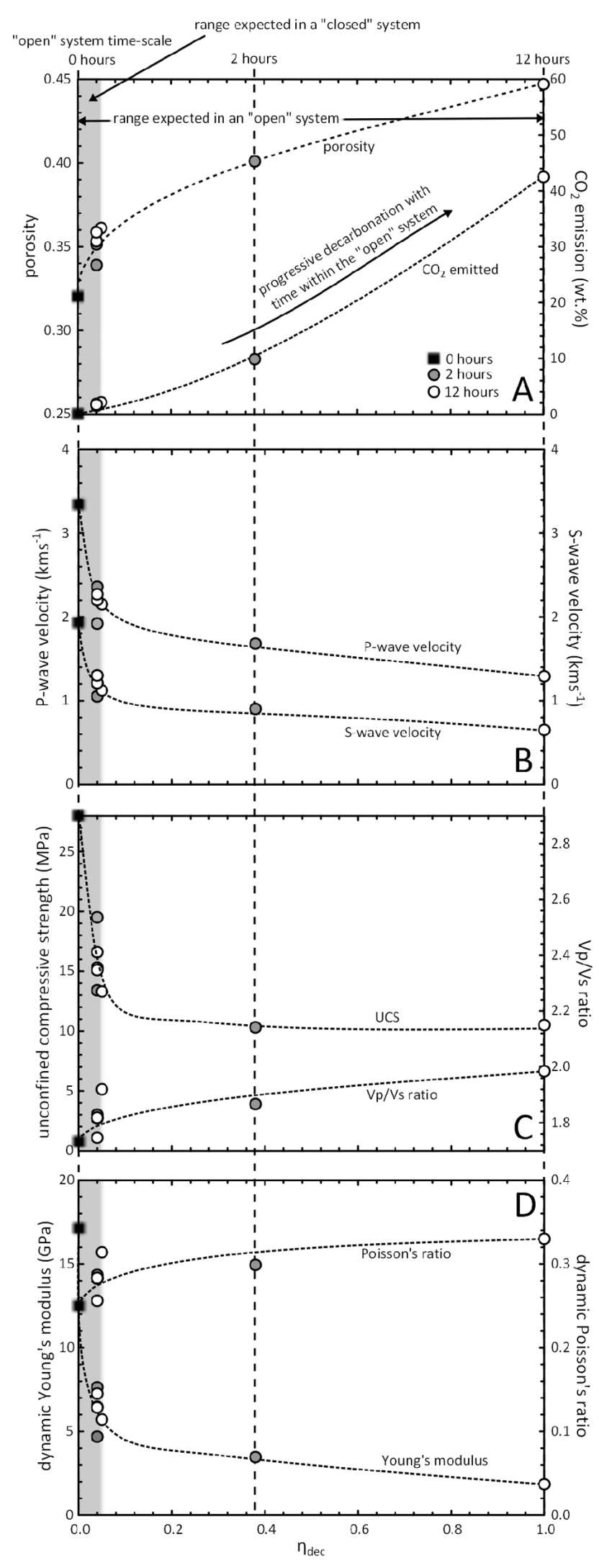

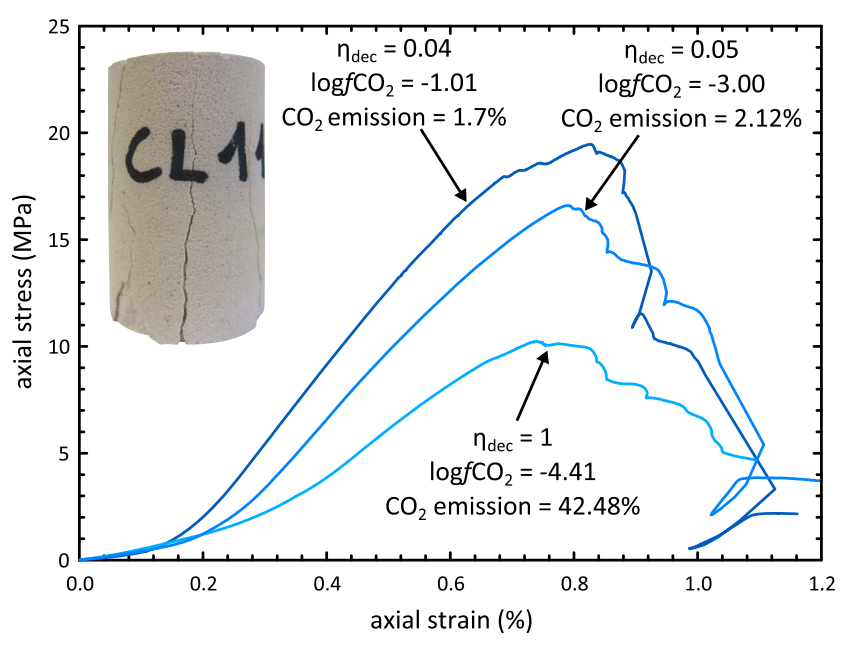

Figure 2. Constant strain rate, uniaxial stress-strain curves for Mt. Climiti limestone. Two curves are for samples decarbonated under a "closed" system $\left(\eta_{\mathrm{dec}}=0.04\right.$ and 0.05$)$, and one curve is for a sample fully thermally-decomposed under an "open" system $\left(\eta_{\mathrm{dec}}=1\right)$.

of the decarbonation reaction. Portlandite was the most abundant mineral phase at $\eta_{\mathrm{dec}}=1$. Portlandite (a calcium hydroxide) forms by the recombination of $\mathrm{CaO}$ (from the decomposition of $\mathrm{CaCO}_{3}$ ) with water vapour in air according to the reaction: $\mathrm{CaO}+\mathrm{H}_{2} \mathrm{O} \rightarrow \mathrm{Ca}(\mathrm{OH})_{2}$. The formation of portlandite in decarbonated limestones was previously observed by Mollo et al. [2011a] and Heap et al. (submitted manuscript, 2012). In contrast to the close-packing of carbonate groups, with calcium present in rhombohedral calcite grains, portlandite has a hexagonal layered crystal structure of calcium oxide layers separated by hydrogen, resulting in a weak interlayer attraction. Therefore, the formation of portlandite drastically influences both microstructure and strength [Nourredine, 2011; Mollo et al., 2011a]. The textural changes caused by such thermal decomposition were imaged using a backscattered SEM. After 12 hours in the "open" system (i.e., $\eta_{\mathrm{dec}}=1$ ), the microstructure had been greatly altered (Figure 4a). The grains (a mixture of portlandite and lime) appear to have been partly dissolved, giving the rock a "sponge-like" texture. The number and dimension of the cavities drastically increased, explaining the large increase in porosity (from 0.32 to 0.45 ). Our approach has shown that, in an "open" system, decarbonation (and the subsequent formation of portlandite) can take place and leads to severe chemical, mineralogical, and textural changes that greatly impact rock physical properties.

Figure 1. The influence of the progression of decarbonation $\left(\eta_{\text {dec }}\right)$ on the physical properties of Mt. Climiti limestone. (a) Porosity. (b) P- and S-wave velocities. (c) Unconfined compressive strength and Vp/Vs ratio. (d) Dynamic Young's modulus and Poisson ratio. The $\mathrm{CO}_{2}$ emission is also shown in A. The physical properties achievable within a "closed" system are confined to the grey region, while the entire plot represents those achievable within an "open" system. The black squares represent the "as-collected" material, and the grey and white circles represent an experiment with a 2 and 12 hour duration, respectively. 


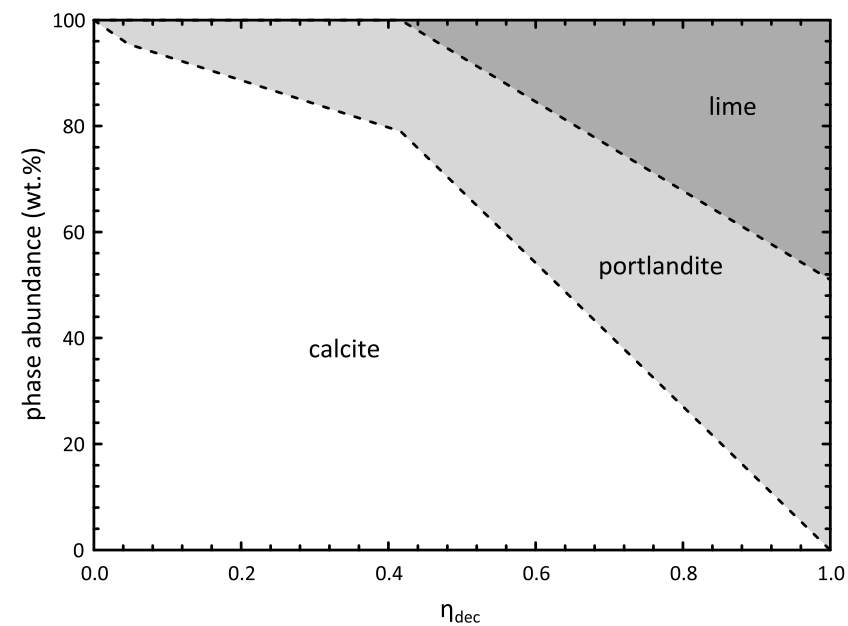

Figure 3. The influence of the progression of decarbonation $\left(\eta_{\mathrm{dec}}\right)$ on the modal composition of Mt. Climiti limestone, as mapped out using a combination of TG, DSC, and XRPD analyses.

[9] However, our experiments reproducing "closed" system conditions all resulted in very low values of $\eta_{\mathrm{dec}}$ (0.04-0.05), even after 12 hours (Figure 1; "closed" system experiments are limited to the grey region). During this time the $\mathrm{CO}_{2}$ emitted from the samples was only $\leq 2.12 \mathrm{wt} . \%$, attesting to the fact that the decarbonation process was essentially stifled by the high $f \mathrm{CO}_{2}$ conditions. Chemical and mineralogical analyses all indicated that, between $\eta_{\text {dec }}=0.04-0.05$, there was mainly calcite present in the sample (Figure 3), and backscattered SEM images (for $\left.\eta_{\mathrm{dec}}=0.04\right)$ showed that there was little change to the rock microstructure, although some microcracks were present (Figure $4 \mathrm{~b}$ ). At $\eta_{\mathrm{dec}}=0.04$, the rock texture was characterized by a network of calcite grains with sparse inter- and intracrystal sub-round cavities. However, MCL rock physical properties were still affected under such "closed" conditions (Figure 1). The Vp, UCS, and dynamic Young's modulus decreased by 34,43 , and $62 \%$, respectively; whereas, relative to the initial properties of the "as-collected" material, porosity and Poisson's ratio increased by 9 and $10 \%$, respectively. The axial stress-strain curves for two samples (with $\eta_{\mathrm{dec}}$ values of 0.04 and 0.05 ) showed qualitatively similar behaviour as for the fully-decomposed sample (Figure 2). The samples still showed a large degree of post-peak strainsoftening, but were ultimately brittle and failed by axial splitting (see inset on Figure 2). However, sample failure was marked by a more obvious stress drop. Since we can rule out severe chemical changes through decarbonation $\left(\eta_{\mathrm{dec}}\right.$ values between 0.04 and 0.05 still indicate that some decarbonation took place), the source of these changes must be explained by another mechanism. The most likely mechanism responsible is thermal microcracking, perhaps prompted by the mild decarbonation. Thermal microcracks will have formed as a result of the build-up of internal stresses due to the thermal expansion anisotropy of calcite; indeed, at $750^{\circ} \mathrm{C}$, the calcite cell-unit volume expands by more than 2\% [Chang et al., 1996]. Thermal microcracks have been previously observed to develop in carbonate rocks above temperatures of $200^{\circ} \mathrm{C}$ [Homand-Etienne and Troalen, 1984]. This hypothesis is supported by the observation of microcracks in the
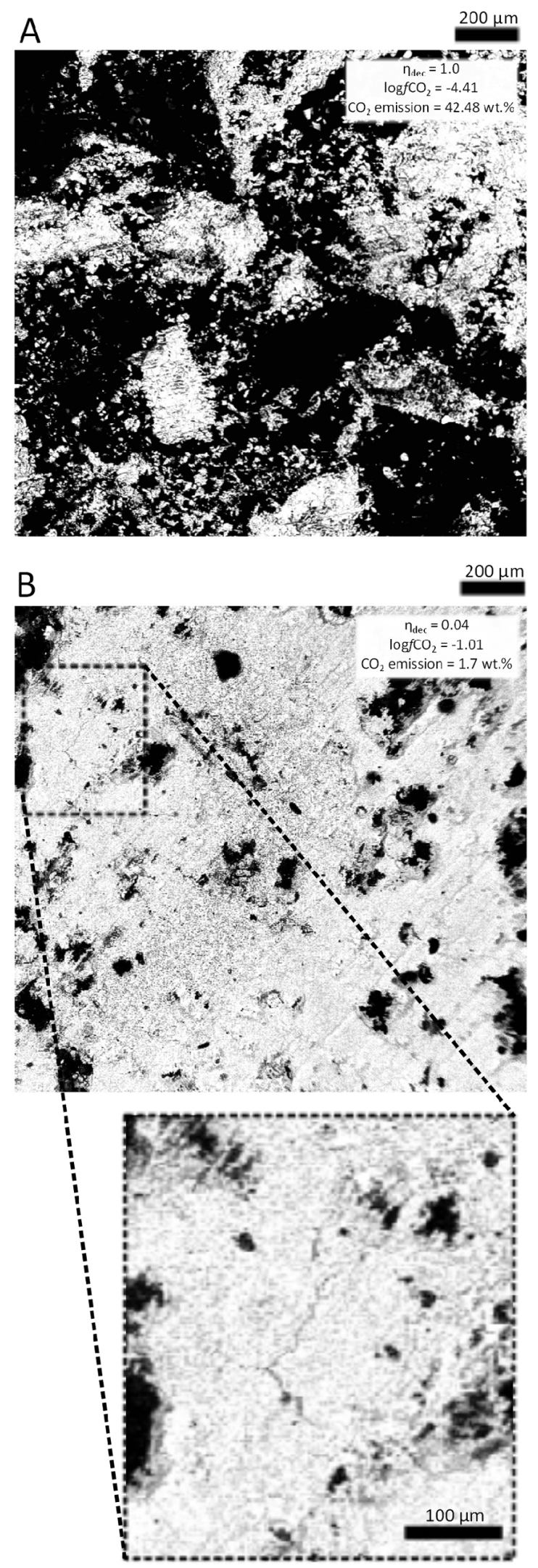

Figure 4. Backscattered SEM images of Mt. Climiti limestone test samples. (a) A fully thermally-decomposed sample $\left(\eta_{\mathrm{dec}}=1\right.$; i.e., an "open" system). (b) A partially-decomposed sample ( $\eta_{\text {dec }}=0.04$; i.e., a "closed" system). The inset shows a zoomed-in image of a thermal microcrack. 
backscattered SEM image of Figure $4 \mathrm{~b}$. These analyses show that, although the decarbonation was halted under such "closed" conditions, and therefore the chemical and mineralogical properties of the rock were largely unaffected, the rock physical properties still suffered as a result of thermal microcracking.

[10] Our results show that decarbonation within an "open" system permits the greatest changes in rock physical properties. However, rock physical properties also deteriorate in a "closed" system, due to thermal microcracking [see also Yavuz et al., 2010, and references therein]. The thermal microcracking within a "closed" system would quickly convert it to an "open" system (since thermal microcracking has been previously shown to dramatically increase permeability, see Jones et al. [1997]). Therefore, given time, $\mathrm{CO}_{2}$ will be quickly and efficiently removed in both scenarios, fuelling decarbonation, and resulting in detrimental changes to rock physical properties.

[11] We propose the following implications of these data for a volcanic edifice with a sub-volcanic sedimentary basement. As explained above, even if the decarbonation process is arrested in a "closed" system, rock physical properties, and therefore edifice stability, will still suffer due to thermal microcracking and the subsequent "opening" of the system. However, perhaps the existence of a "closed" system in a volcanic edifice is a somewhat unrealistic scenario. Volcanic rocks are often porous, permeable [Mueller et al., 2005], and contain a high degree of microcracking [Vinciguerra et al., 2005; Heap et al., 2011]. Further, volcanoes are often home to large-scale fault systems that can act as effective pathways for degassing (e.g., the Pernicana fault at Mt. Etna [Giammanco et al., 1998]). To return to our case study, the amount of $\mathrm{CO}_{2}$ outgassed from Mt. Etna volcano makes it one of the largest $\mathrm{CO}_{2}$-producing volcanoes in the world. However, only $13 \mathrm{Mt}$ of the total yearly output $(25 \mathrm{Mt})$ comes from the summit craters, the rest degasses from its flanks through active faults [Bruno et al., 2001, and references therein]. Further, the large amounts of $\mathrm{CO}_{2}$ that are emitted diffusely from the soil, or dissolved into Etnean aquifers, suggests that pure $\mathrm{CO}_{2}$ and $\mathrm{CO}_{2}$-saturated brines can move up along deep fractured zones [Giammanco et al., 1998; Federico et al., 2011]. It is well known that $\mathrm{CO}_{2}$ is exsolved and released by ascending magma, due to its abundance and low solubility in silicate melts [Freda et al., 2008, and references therein]. However, the assumption that $\mathrm{CO}_{2}$ degassing at $\mathrm{Mt}$. Etna is entirely magmatic in origin leads to a gross overestimate of the volume of magma during pre-eruptive ascent [D'Alessandro et al., 1997]. This implies that a significant fraction of the volume of $\mathrm{CO}_{2}$ outgassed from Mt. Etna must come from a "non-magmatic source". Indeed, it has been recently suggested that the carbon isotopic signature of volcanic $\mathrm{CO}_{2}$ from Mt. Etna could have a crustal origin related to the interaction of carbonates with hot mantle-derived magmas [Chiodini et al., 2011]. For example, a rise in $\delta^{13} \mathrm{C}$ has been recently measured at Merapi volcano (Central Java) and was attributed to a considerable addition of crustal $\mathrm{CO}_{2}$ that supplemented the mantle-derived volatile flux, intensifying and sustaining the 2006 eruption [Troll et al., 2012]. It therefore seems likely that the permeable nature of a volcanic edifice at Mt. Etna provides ample pathways for the $\mathrm{CO}_{2}$ produced during decarbonation to escape (i.e., an "open" system), which will facilitate further decarbonation.
Therefore, we propose that Mt. Etna volcano is at significant risk for decarbonation-driven instability.

[12] Since the physical and mechanical properties of basaltic rocks from Mt. Etna volcano do not significantly change at relatively high (up to $800^{\circ} \mathrm{C}$ ) temperatures [Mollo et al., 2011a], the thermal-weakening of the carbonate basement rocks may be interpreted as one of the main processes altering the structural integrity of the volcano. Indeed, accelerated flank movements are commonly observed to follow magmatic events within the sub-volcanic basement at Mt. Etna [Walter et al., 2005], highlighting the intimate relationship between the heating of the carbonate basement and the instability of the volcanic edifice. Further, long-term records of $\mathrm{CO}_{2}$ degassing at Mt. Etna has also shown that high soil $\mathrm{CO}_{2}$ fluxes are strictly related to the dynamics of magma ascent, a marked sliding of the eastern flank, and increased seismicity [Federico et al., 2011]. It emerges therefore that carbonate basement decomposition at Mt. Etna may be the origin of low ultrasonic wave velocity zones [cf., Patanè et al., 2006], preferential sliding surfaces [Froger et al., 2001; Neri et al., 2004; Lundgren et al., 2004], the large-scale ESE seaward sliding of the eastern flank [e.g., Palano et al., 2009; Heap et al., submitted manuscript, 2012], and crustal-derived $\mathrm{CO}_{2}$ emissions [Chiodini et al., 2011; Heap et al., submitted manuscript, 2012]. We deduce that similar processes could be operative at high-risk volcanoes with sub-volcanic carbonate basements worldwide.

[13] Acknowledgments. S. Mollo was supported by the ERC Starting grant 259256 GLASS project. M. J. Heap and D. B. Dingwell acknowledge the support of a Hubert Curien Partnership (PHC) PROCOPE grant (grant 27061UE), the Deutscher Akademischer Austauschdienst (DAAD) in Germany, and the Ministry of Foreign and European Affairs (MAE) and the Ministry of Higher Education and Research (MESR), both in France. Dingwell also acknowledges a research professorship from the Bundesexzellenzinitiative (LMU excellent) and the ERC Advanced grant EVOKES (247076). We thank Thierry Reuschlé for his assistance in the laboratory at EOST. We are also indebted to the insightful comments of one reviewer and the editor Andrew Newman.

[14] The Editor thanks Christian Huber for assisting in the evaluation of this paper.

\section{References}

Acocella, V., and G. Puglisi (2010), Hazard mitigation of unstable volcanic edifices, Eos Trans. $A G U$, 91(40), 357-358, doi:10.1029 2010 EO400002.

Barnes, C. G., T. Prestvik, B. Sundvoll, and D. Surratt (2005), Pervasive assimilation of carbonate and silicate rocks in the Hortavær igneous complex, north-central Norway, Lithos, 80, 179-199, doi:10.1016/ j.lithos.2003.11.002.

Bonaccorso, A., G. Currenti, C. Del Negro, and E. Boschi (2010), Dike deflection modelling for inferring magma pressure and withdrawal, with application to Etna 2001 case, Earth Planet. Sci. Lett., 293, 121-129, doi:10.1016/j.eps1.2010.02.030

Bonforte, A., S. Gambino, and M. Neri (2009), Intrusion of eccentric dikes: The case of the 2001 eruption and its role in the dynamics of Mt. Etna volcano, Tectonophysics, 471, 78-86, doi:10.1016/j.tecto.2008.09.028.

Bruno, N., T. Caltabiano, S. Giammanco, and R. Romano (2001), Degassing of $\mathrm{SO}_{2}$ and $\mathrm{CO}_{2}$ at Mount Etna (Sicily) as an indicator of preeruptive ascent and shallow emplacement of magma, J. Volcanol. Geotherm. Res., 110, 137-153, doi:10.1016/S0377-0273(01)00201-3.

Chang, L. L. Y., R. A. Howie, and J. Zussman (1996), Rock-Forming Minerals, vol. 5B, Non-silicates: Sulphates, Carbonates, Phosphates, Halides, 2nd ed., Longman, Essex, U. K.

Chiodini, G., S. Caliro, A. Aiuppa, R. Avino, D. Granieri, M. Moretti, and F. Parello (2011), First ${ }^{13} \mathrm{C} /{ }^{12} \mathrm{C}$ isotopic characterisation of volcanic plume $\mathrm{CO}_{2}$, Bull. Volcanol., 73, 531-542, doi:10.1007/s00445-0100423-2.

D’Alessandro, W. D., S. Giammanco, F. Parello, and M. Valenza (1997), $\mathrm{CO}_{2}$ output and $\delta^{13} \mathrm{C}\left(\mathrm{CO}_{2}\right)$ from Mount Etna as indicators of degassing of shallow asthenosphere, Bull. Volcanol., 58, 455-458, doi:10.1007/ s004450050154. 
Di Rocco, T., C. Freda, M. Gaeta, S. Mollo, and L. Dallai (2012), Magma chambers emplaced in carbonate substrate: Petrogenesis of skarn and cumulate rocks and implication on $\mathrm{CO}_{2}$ - degassing in volcanic areas, J. Petrol., doi:10.1093/petrology/EGS051, in press.

Federico, C., M. Camarda, S. De Gregorio, and S. Guerrieri (2011), Longterm record of $\mathrm{CO}_{2}$ degassing along Mt. Etna's flanks and its relationship with magma dynamics and eastern flank instability, Geochem. Geophys. Geosyst., 12, Q10002, doi:10.1029/2011GC003601.

Freda, C., M. Gaeta, V. Misiti, S. Mollo, D. Dolfi, and P. Scarlato (2008), Magma-carbonate interaction: An experimental study on ultrapotassic rocks from Alban Hills (central Italy), Lithos, 101, 397-415, doi:10.1016/ j.lithos.2007.08.008.

Froger, J.-L., O. Merle, and P. Briole (2001), Active spreading and regional extension at Mount Etna imaged by SAR interferometry, Earth Planet. Sci. Lett., 187, 245-258, doi:10.1016/S0012-821X(01)00290-4.

Giammanco, S., S. Gurrieri, and M. Valenza (1998), Anomalous soil $\mathrm{CO}_{2}$ degassing in relation to faults and eruptive fissures on Mount Etna (Sicily, Italy), Bull. Volcanol., 60, 252-259, doi:10.1007/s004450050231.

Grasso, M., and F. Lentini (1982), Sedimentary and tectonic evolution of the eastern Hyblean Plateau (southeastern Sicily) during late Cretaceous to Quaternary time, Palaeogeogr. Palaeoclimatol. Palaeoecol., 39, 261-280, doi:10.1016/0031-0182(82)90025-6.

Guéguen, Y., and V. Palciauskas (1994), Introduction to the Physics of Rocks, 294 pp., Princeton Univ. Press, Princeton, N. J.

Heap, M. J., P. Baud, P. G. Meredith, S. Vinciguerra, A. F. Bell, and I. G. Main (2011), Brittle creep in basalt and its application to time-dependent volcano deformation, Earth Planet. Sci. Lett., 307, 71-82, doi:10.1016/j. eps1.2011.04.035.

Homand-Etienne, F., and J.-P. Troalen (1984), Behaviour of granites and limestones subjected subjected to slow and homogenous temperature changes, Eng. Geol., 20, 219-233, doi:10.1016/0013-7952(84)90002-4.

Jones, C., G. Keaney, P. G. Meredith, and S. A. F. Murrell (1997), Acoustic emission and fluid permeability measurements on thermally cracked rocks, Phys. Chem. Earth, 22, 13-17, doi:10.1016/S0079-1946(97) 00071-2.

Khinast, J., G. F. Krammer, C. Brunner, and G. Staudinger (1996), Decomposition of limestone: The influence of $\mathrm{CO}_{2}$ and particle size on the reaction rate, Chem. Eng. Sci., 51, 623-634, doi:10.1016/0009-2509 (95)00302-9.

Lentini, F. (1982), The geology of the Mt. Etna basement, Mem. Soc. Geol. Ital., 23, 7-25.

Lundgren, P., F. Casu, M. Manzo, A. Pepe, P. Berardino, E. Sansosti, and R. Lanari (2004), Gravity and magma induced spreading of Mount Etna volcano revealed by satellite radar interferometry, Geophys. Res. Lett., 31, L04602, doi:10.1029/2003GL018736.

Mollo, S., P. Del Gaudio, G. Ventura, G. Iezzi, and P. Scarlato (2010a), Dependence of clinopyroxene composition on cooling rate in basaltic magmas: Implications for thermobarometry, Lithos, 118, 302-312, doi:10.1016/j.lithos.2010.05.006.

Mollo, S., M. Gaeta, C. Freda, T. Di Rocco, V. Misiti, P. Scarlato (2010b), Carbonate assimilation in magmas: A reappraisal based on experimental petrology, Lithos, 114, 503-514.

Mollo, S., S. Vinciguerra, G. Iezzi, A. Iarocci, P. Scarlato, M. J. Heap, and D. B. Dingwell (2011a), Volcanic edifice weakening via devolatilization reactions, Geophys. J. Int., 186, 1073-1077, doi:10.1111/j.1365-246X. 2011.05097.x.
Mollo, S., K. Putirka, G. Iezzi, P. Del Gaudio, and P. Scarlato (2011b), Plagioclase-melt (dis)equilibrium due to cooling dynamics: Implications for thermometry, barometry and hygrometry, Lithos, 125, 221-235, doi:10.1016/j.lithos.2011.02.008.

Mueller, S., O. Melnik, O. Spieler, B. Scheu, and D. B. Dingwell (2005), Permeability and degassing of dome lavas undergoing rapid decompression: An experimental determination, Bull. Volcanol., 67 526-538, doi:10.1007/s00445-004-0392-4.

Neri, M., V. Acocella, and B. Behncke (2004), The role of the Pernicana Fault System in the spreading of Mt. Etna (Italy) during the 2002-2003 eruption, Bull. Volcanol., 66, 417-430, doi:10.1007/s00445-003-0322-x.

Nourredine, A. (2011), Influence of curing conditions on durability of alkali-resistant glass fibres in cement matrix, Bull. Mater. Sci., 34, 775-783, doi:10.1007/s12034-011-0194-1.

Palano, M., S. Gresta, and G. Puglisi (2009), Time-dependent deformation of the eastern flank of Mt. Etna: After-slip or viscoelastic relaxation?, Tectonophysics, 473, 300-311, doi:10.1016/j.tecto.2009.02.047.

Patanè, D., G. Barberi, O. Cocina, P. De Gori, and C. Chiarabba (2006), Time-resolved seismic tomography detects magma intrusions at Mount Etna, Science, 313, 821-823, doi:10.1126/science.1127724.

Samtani, M., D. Dollimore, and K. S. Alexander (2002), Comparison of dolomite decomposition kinetics with related carbonates and the effect of procedural variables on its kinetic parameters, Thermochim. Acta, 392-393, 135-145, doi:10.1016/S0040-6031(02)00094-1.

Tibaldi, A., and G. Groppelli (2002), Volcano-tectonic activity along structures of the unstable NE flank of Mt. Etna (Italy) and their possible origin, J. Volcanol. Geotherm. Res., 115, 277-302, doi:10.1016/S03770273(01)00305-5.

Troll, V. R., D. R. Hilton, E. M. Jolis, J. P. Chadwick, L. S. Blythe, F. M. Deegan, L. M. Schwarzkopf, and M. Zimmer (2012), Crustal $\mathrm{CO}_{2}$ liberation during the 2006 eruption and earthquake events at Merapi volcano, Indonesia, Geophys. Res. Lett., 39, L11302, doi:10.1029/ 2012 GL051307.

Van Wyk de Vries, B., and A. Borgia (1996), The role of basement in volcano deformation, in Volcano Instability on the Earth Other Planets, edited by W. J. McGuire, A. P. Jones, and J. Neuberg, Spec. Publ. Geol. Soc., 110, 95-110.

Vinciguerra, S., C. Trovato, P. G. Meredith, and P. M. Benson (2005), Relating seismic velocities, thermal cracking and permeability in Mt. Etna and Iceland basalts, Int. J. Rock Mech. Min. Sci., 42, 900-910, doi:10.1016/j.ijrmms.2005.05.022.

Walter, T. R., V. Acocella, M. Neri, and F. Amelung (2005), Feedback processes between magmatic events and flank movement at Mount Etna (Italy) during the 2002-2003 eruption, J. Geophys. Res., 110, B10205, doi:10.1029/2005JB003688.

Wang, Y., and W. J. Thomson (1995), The effects of steam and carbondioxide on calcite decomposition using dynamic X-ray-diffraction, Chem. Eng. Sci., 50, 1373-1382, doi:10.1016/0009-2509(95)00002-M.

Wenzel, T., L. Baumgartner, G. E. Bruugmann, E. G. Konnikov, and E. Kislov (2002), Partial melting and assimilation of dolomitic xenoliths by mafic magma: The Ioko-Dovyren intrusion (North Baikal Region, Russia), J. Petrol., 43, 2049-2074, doi:10.1093/petrology/43.11.2049.

Yavuz, H., S. Demirdag, and S. Caran (2010), Thermal effect on the physical properties of carbonate rocks, Int. J. Rock Mech. Min. Sci., 47, 94-103, doi:10.1016/j.ijrmms.2009.09.014. 